Journal of Ancient Philosophy Vol. II 2008 Issue 2

\title{
Thumos and the Daring Soul: Craving Honor and Justice
}

\author{
Susan M. Purviance (University of Toledo, Ohio)
}

The Greek conception of the spirited aspect of soul reaches back to the Pre-Socratics and to the Homeric tradition, and is crucial to tragedy. In public assembly for political protest, perceptions, passions, and embodied ways of knowing are put into action.This work is a philosophical examination of indignation. I examine the Greek notion of the spirited part of the soul which resents injury and resists injustice. To take actions for the sake of one's moral and political dignity and for the moral dignity of others may involve the risking arrest and detention. Challenging the wishes of the political authority to which one owes allegiance has psychosomatic effects. To examine these effects from the point of view of Greek psychic descriptions is the purpose of this study. Both Homeric and tragedic Greek literary contexts, and a contemporary incident of civil disobedience, will inform this discussion.

The human soul may be thought of as the distinctively human way of being aware of and acting in one's environment. That being so, it is perhaps best understood as the multiply layered and deeply interactive set of psychic capacities that we become acquainted with in the works of Aristotle. Such a conception of psyche, a psyche understood as the reflexively mediated set of capacities for human living, derives from culturally deep sources. It has a long taproot reaching back to the Pre-Socratics and to the Homeric tradition. In public assembly for political protest, perceptions, passions, and embodied ways of knowing are put into action. This work is a philosophical examination of indignation, honor, and justice. I examine the Greek notion of the spirited part of the soul which seek honor, resents injury and resists injustice. To take actions for the sake of one's moral and political dignity and for the moral dignity of others may involve the risking arrest and detention. Challenging the wishes of the political authority to which one owes allegiance has psychosomatic effects. To examine these effects from the point of view of Greek psychic descriptions is the purpose of this study. Homeric and tragedic Greek literary texts will inform this 
Journal of Ancient Philosophy Vol. II 2008 Issue 2

discussion.

One could argue that the key elements of Aristotle's conception of soul are the height of the Greek account of practical reason. These include such elements as nous, in its grasp of theoretical and practical truth and its application to scientific and practical judgment, and hexis, as the formations of habitual patterns of response, both moral and intellectual. Such a view is plausible. Yet this study is about matters of political and moral judgment as seen in particular epic, tragedic, and philosophical contexts, and for that investigation one needs to concentrate on the psychic element known as thumos. Thus, this project reviews thumos and presents its typical disruptive emergence in social situations, its voice or tenor, and the problematic surrounding its message to the agent and the validity of its "suggestions". It analyzes its initial multivalent position in Homeric thought and resists Plato's and Aristotle's tendency to marginalize and to re-conceive it politically and philosophically. A full examination of Plato's and Aristotle's projects with respect to the spirited component of soul and its character tendencies is not intended, however some review is in order.

Plato reduces and localizes thumos to the flaw of thumoietic, irascible, character. Such shorttemperedness and irascibility interrupts the operation of nous, making the person more fit for battle than for peace (Republic VII 547e) and takes away the patience and good will needed for the philosophical pursuit of truth (Republic II). But as Jean Frère asks, " to what extent is the desire for truth (epithumia) yet linked to the thumos that craves truth and justice?"1 Frère notes that three psychic terms, thumos, epithumia (desire), and prothumia (ardent desire) share the same root and can be said to join in a common implication of dynamism and warm feeling in service of it. This then suggests that a feeling for the political truth and hatred of political lies must be active in political engagement in public life, an engagement that is not cut off from strong feeling which prompts to active dissent.

Aristotle treats thumos as marginal to political life in a well-ordered state. Yet one could

\footnotetext{
${ }^{1}$ Jean Frère, les Grecs et le désir de l'etre : des préplatoniciens à Aristotle, Société d'Edition « Les Belles Lettres » ( Paris, 1981), p. 7.
} 
Journal of Ancient Philosophy Vol. II 2008 Issue 2

argue that commonwealths are not always well-ordered, wise, or true to their values, and that in such cases political action requires that agents have a number of psychic abilities related to strong indignation. One needs spirited perception and engaged imagination, along with the ability to sustain uncomfortable motivational states, in order to be able to stand one's ground and suffer hardship. It is true that Aristotle abandons the root term thumos when discussing virtue, preferring to speak of the role of anger (orge) in the rightly motivated person and courage in the brave (enthumos) person. Nonetheless, it is the very structure of Aristotle's account of moral perception and reason which leads me to re-position thumos in a postmodern and post-liberal theory of political disobedience. For the Aristotelian mean with respect to anger may allow for a rehabilitation of virtues which derives, at least in part, from the complex of narratives of the irascible hero. Aristotle writes

For in everything it is no easy task to find the middle, e.g. to find the middle of a circle is not for every one but for him who knows; so, too, any one can get angry — that is easy — or give or spend money; but to do this to the right person, to the right extent, at the right time, with the right motive, and in the right way, that is not for every one, nor is it easy; wherefore goodness is rare and laudable and noble. (EN II.9 1109a23-29)

Hence, roused and released anger, a marker of indignation and perceived injustice, may be implicated in the difficult act, or even the just act. To undertake this analysis of the body as a source of perceptions of treachery and injustice is to uncover the full reach of the psyche into the body core, its thoracic homeland

This is not to say that spiritedness is permanently at odds with the social world; rather it acts out when its normal course of legitimate self-seeking is blocked. The analysis undertaken here leads to the conclusion that there are three principal expressions of thumos in political life. These three expressions of spirited engagement continue to be seen in contemporary resistance to injustice and may help to inform our understanding of the need to resist political authority. In civic life, this psychic element invigorates, detonates, or disrupts.

-A. Thumos invigorates: Thumos energizes civic life as a spirited pursuit of honor in any 
Journal of Ancient Philosophy Vol. II 2008 Issue 2

competition that is regulated to produce a social good.

-B. Thumos detonates: Thumos causes civic life to explode, as in riot, revolution, factionalism, or stasis, a stalemate of factions in government, making its victims incapable of self-governance.

- C. Thumos disrupts: Thumos disrupt civic life positively in civil disobedience and direct protest designed to reveal conditions of injustice.

By invigorating citizens thumos bolsters civil life, leading to economic, cultural, and political vitality. By detonating or igniting passions for self-respect and good reputation, thumos can lead to actions that destroy civic life, since the agent loses all fear of the sanctions which authorities would impose. Thirdly, thumos disrupts oridinary civic order, but does not destroy it, becoming another form of the public's way of doing political business with its rulers. For example, public demonstrations communication, commerce and transportation but enhance civic engagement by those who are politically alienated.

One can find examples of these three effects in the Greek account of spiritedness. First of all, spiritedness produced an invigorated populace when competition between male citizens was normalized - for a time and in Athens, it is kept on a loose rein and praised. Deeds done from proper ambition for accomplishment and honor strengthen civic life; they are a bulwark against external and internal enemies. Secondly there are many Greek examples of its toxic or explosive malfunction. Here one sees a spiritedness of excess and transgression, a wholly destructive form in which it appears as a ravenous beast, or as a wildfire of rage. Beasts do not live in or maintain societies. Like a beast, it consumes its victim and overturns civic life. The third function is of greatest interest to democratic societies. Here the spirited soul acts ambivalently: its leonine daring disrupts civic life, yet in sometimes necessary ways. ${ }^{2}$ It is this third ambivalent form which is able

2 In addition to civil disobedience in time of injustice one can cite Solon in support of this function of thumos. Solon says that thumos has a legitimate place in political activity in time of stasis (political upheaval), because when others are destroying the city and its values out of thumoeitic excess, the thumos of good men rouses them to intervene and take countermeasures. During stasis, the natural fear of death in mob violence that grips the just man but the spirited aspect of soul overcomes this fear and gives him courage to act. To remain neutral or to hide out of fear is not a permissible option, not because stasis or factionalism is good, but because it is so bad. See Kostas Kalimtzis, Aristotle on Political Emnity and Disease (SUNY Press, 2000) pp.145-6. 
Journal of Ancient Philosophy Vol. II 2008 Issue 2

at times to occupy the Aristotelian mean or middle position relative to us and context. The spirited soul which dares civil disobedience challenges the prejudices against it that we have gained from its ridicule in Plato's Republic. A full treatment of the invigorating, detonating, and disruptive/corrective functions cannot be given here, but the hope is that this sketch of a some dispositions of thumos as the mean relative to us will help to reveal the psychic structure of certain forms of political resistance.

\section{Thumos as vitality and invigoration : the path to decisive action under threat of harm or death}

In the epic Homeric context, thumos is associated with the conscious control of the body. It leaves the body in a swoon or concussion, and returns to the body upon revival, while by contrast when psyche exits the body death results. According to Caswell ${ }^{3}$ the connection between thumos and the breath in living things is strong, since thumos returns when the person breathes again. Caswell argues that early Greeks modeled their understanding of psychic and divine states on the natural elements, thus thumos is a sort of inner wind that stirs up and rouses the person to action, a sort of turbulent inner sea rolling in the person. This suggests that deliberation was imagined as a sloshing motion of to-and-fro movement. The aptness of the metaphor to the phenomenal feel of deliberation and rousing to action is striking. In the Homeric passages that feature deliberation thumos is often parallel with phren/phrenes, which is or are the physical correlate or "meat" of the "smarts" in us. By contrast, when the context is motivational rather than deliberative, thumos appears in parallel constructions with menos. Diction then marked a difference between activating assessment of alternatives and their consequences, and activating a motivational state that is interested in realizing an outcome. ${ }^{4}$ How is it then that thumos registers both the feel of the pull of differing outcomes, and also the motivation gearing up in response to powerful passions? Homer makes this clear. Thumos is what supports acts of daring and enables a Homeric hero to suffer, to

\footnotetext{
${ }^{3}$ Caroline P. Caswell, A Study of Thumos in Early Greek Epic (E.J. Brill, 1990), pp.12-114.

${ }^{4}$ The agitated image of acting from anger or indignation is also apparent in the verb otruno, "to stir up, rouse, encourage", which is often employed in discussions of a course of action under deliberation.
} 
Journal of Ancient Philosophy Vol. II 2008 Issue 2

endure, and to dare awful things. In virtue of his thumos, or spirited soul, the hero becomes tlemon, bold and stout-hearted. He is resolved and acts. Intellect depends on motive force, and deliberation is inner motion. It would appear that motion is first concentrated and then finally released, with decision in its awful feel retaining the emotional thrust generated by turbulent motions of the spirited soul. Although decision is a firm, settled state, it is not quiescent, at least under the extreme pressures of heroic action. Just as the sailors cannot set sail and follow a course until Zeus or Poseidon permits it, the intellect (phren) sets the course in concert with the spirited part of the soul. ${ }^{5}$

Thumos has a place in body as well as in thought, making it relevant to contemporary philosophical notions of mind and corporeality. It functions as a source of insight and motivation and is localized in the thoracic cavity, where the motions of the diaphragm and the lungs occur and are felt. How one breathes is of course an indication of the psychic condition of the individual, since emotions affect the pattern and depth of breathing and register adrenalin surges. In Homeric anatomy spirited soul interpenetrates the organ of thought (the phrenes) which itself surrounds the heart (the kardia) in the chest. This soul function is one of pressing on the heart-area and contracting and expanding it in ways often viscerally felt. Psychophysically, the swelling/heaving/lurching soulfunction that is thumos should not be thought of as an organ or as a merely anatomical assignment of psychic states. Rather it should be taken to be an effect on organs and on psyche generally in a particular embodiment. In its intense motion it puffs up the chest and stiffens the body and so too the person's thinking. This is pride and arrogance. At other times the intense motion of thumos moves the phrenes to contract and tighten painfully within the chest; this appears as the familiar feeling of unbearable grief and sorrow.

In its most violent movements thumos heaves, lurches inside us, and swells, as when our heart "swells with pride" or our gut "lurches with alarm" or our soul "heaves with grief". But how can we understand such experiences? Do they comport with the Greek poetic, tragedic, and philosophical psychology under examination? Aristotelian practical reason depends upon right

\footnotetext{
${ }^{5}$ Caswell, pp.2-4.
} 
Journal of Ancient Philosophy Vol. II 2008 Issue 2

perceptions and upon being pleased or pained at the right things. Thumos can help or hinder right perception since it gives those perceptions their emotional tone. Greek epic poetry also models how to perceive correctly and act rightly in a dangerous situation. In the Iliad Diomedes praises Odyesseus : “...whose eager heart and manly $\theta 0 \mu$ ó $\varsigma$ excel in all sorts of trials, and Pallas Athene loves him. If he were to go with me, we should both return even out of blazing fire, since he excels

in the use of his vóos." " Here thumos is praised for its role in rational thinking along with noos/nous.

In epic poetry and in drama the thumos is addressed dialogically. Characters deliberate by considering their alternatives and the consequences for their virtue or honor. Sometimes their thumos is said to address them or they to address it, and this dialogue is represented in indirect discourse in the narrative. To the extent that we identify with the characters and with their situation, thumos speaks both to and for the fearful part of us, as in this instance at Iliad 11/401-411 Odysseus is surrounded in battle and fears for his life:

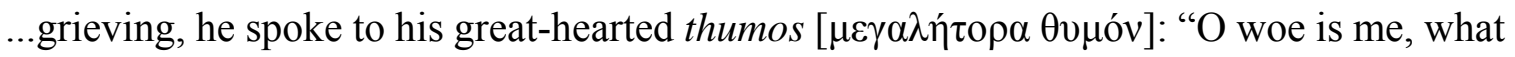
am I to endure? It is a great act of cowardice if I should take flight, terrified by the numbers of men; but it will be worse if I am taken alone; the son of Kronos put the other Danaans to flight. But why has my dear $\theta v \mu$ ó $̧$ discussed these things in me? I know that cowards leave the battle, but he who excels in battle must stand his ground strongly, whether he is hit or hits another."7

Odyesseus' thumos is his great seat of passion, of life, of reason. It reasons in and with him, pointing out what it would mean, that is, how it would feel to run or to stand his ground. It invigorates him to use his life in a manner that risks life in an honorable way.

\section{Thumos as detonation, thumos as disruption: primal rage, riot, and revenge}

\footnotetext{
${ }^{6}$ Iliad X 244-247/ p.25 Caswell.

7 Translated in Caswell, 45.
} 
Journal of Ancient Philosophy Vol. II 2008 Issue 2

The motions of the motive and deliberative aspects of the spirited soul differ by temperament and are more violent in some people. The earliest poetic references to thumos treat it as a beast that inhabits the gut, a kind of inner corporeal being that lays low at most times but rears up in its bodily

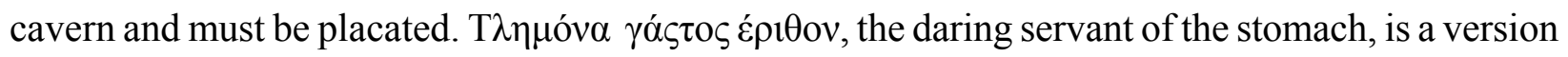
of the inner-man/beast that also imposes the satisfaction of its needs on the civilized man. As Pietro Pucci argues, "The gaster is portrayed as a lower thumos, a vital principle that forces upon men its irresistible needs; it lives as an entity, let us say as a beast, inside man and needs to be taken care of, fed, and listened to." ${ }^{8}$ Plato's discussion of thumos in Republic recalls this knowledge: it is better to let this beast neither be starved nor overfed, but kept sleeping deep in its body cavity. ${ }^{9}$ This is thumos as the ravenous beas. When thumos creates factionalism, the civic body is torn apart. If this happens violently as in revolt or revolution, there is violence and destruction in the community. The person of good character that observes the violence is repulsed. When the untamed soul or uninhibited ferocious aspect rages at perceived, and often real, injustices, the disapproval of the injustice can be overwhelmed by the revulsion felt against the violent means used to point it out.

It is clear that the spirited soul can lead to social breakdown. Returning to Homer one finds examples of thumoeitic behavior that threaten to destroy Greek social order. At the battle of Troy Achilles refuses to fight after Agamemnon wrongs him. The selfish rage of Achilles is not fully ripened into a violent outburst, but the angry sulking almost removes the Greeks' chance of success. Eventually Achilles is persuaded to relent from his refusal to fight. Yet at the moment when Achilles refuses to come to battle (Iliad Twenty-four 39-43), total destruction of the Greek forces threatens.

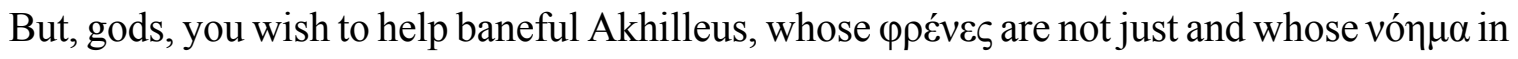
his chest cannot be bent, since he knows wild things like a lion, who, having yielded to his great

\footnotetext{
${ }^{8}$ Pucci, Odysseus Polutropos: Intertextual Readings in the Odyssey and the Iliad, Cornell University Press (Ithaca 1987) as cited in Joshua T. Katz, "Homeric Hymn to Hermes 296", Classical Quarterly New Series Volume 49 number 1 (1999), p.317-318.

${ }^{9}$ Republic IX 571e.
} 
Journal of Ancient Philosophy Vol. II 2008 Issue 2

force and his mighty $\theta v \mu$ ó $\zeta$, will attack men's flocks in order to seize a feast,... ${ }^{10}$

This beast will destroy human society if it can, like a lion slowly picking off its prey with impunity. Achilles knows wild things like a lion in that he is yielding to his arrogance and its irrational point of view. Achilles thinks 'does it really matter whether we act nobly or not, since we die either way?' (Iliad Nine 318-322). His thumos is kakos, wrong in him. In a fine image, Homer tells us that his soul is sideereos, or hard as iron. And even when Achilles returns to battle, the thumoietic mechanism is at work: returns because his thumos grieves so much at Patroklos's death.

In thumos released from the strictures of justice, the ego expands and swells and preens itself in a reverie of self-righteousness and self-importance. No one shows us this better than Euripides in his Medea. Medea helps Jason win the golden fleece and in gratitude he marries her, then returns to Thebes. Having arranged for a regicide there, they flee on to Corinth, where Jason finds a chance to improve his position by rejecting Medea and taking on a new, less fierce princess. He looks to Creon's daughter to bear him more sons to enhance his legacy. When Medea is abandoned she calls for justice from Themis, goddess of oaths and daughter of Zeus. Medea revenges herself, but also the gods, since they too are offended by Jason's breaking of his promise to her. She does this not by killing Jason, but by killing those he loves.

Various versions of the Medea story exist in Greek thought. Although in some of them Medea does not kill her children, I shall take Euripides' play as paradigmatic of a certain function of spiritedness. What do Medea's character and act demonstrate about thumos as detonation? Euripides sees into the thumoeitic personality very deeply. Its irrationalism, is ability to destroy its own means of survival, becomes piteous and thus humanly possible. Unexcused, yet human. Why would humans destroy their own families? Insofar as destroying families who rule destroys civic order, why would they tear apart their own communities? Why would we destroy what we most value? What is the emotional logic at work? As seen in divinely ordained yet savagely enacted vengeance of Medea on Jason the results of thumos may be unnatural as well as irrational. Here self-

\footnotetext{
${ }^{10}$ Caswell p.23.
} 
Journal of Ancient Philosophy Vol. II 2008 Issue 2

righteousness, the evil underside of righteous indignation, reigns. Yet like thumos as disruption in contrast with thumos as detonation, Medea stands sometimes in righteousness, sometimes in excess and unnaturalness. To see this, first consider the aspects of unnatural excess, as seen in Medea's exultation in the death of her rival. Later, consider her spirited deliberation and vacillation over whether to kill Jason's sons, recalling them in light of Odyesseus' deliberations.

\section{Thumos as detonation: the conflagration}

Medea represents spirited soul as destroyer of civic life. After Jason degrades her as a wife and she loses any rightful place in Theban life, she exacts her own penalty. Here is the pleasure of vengeance pure and simple. Here the excuse of taking justice into her own hands appears to be a justification for indulging in cruelty. The thumoeitic flaw is no longer a dialogue with honor, as in the case of Odysseus, but rather a soliloquy of self-justification. To demi-gods like Medea, mere mortals sometimes look like insects. After her rival is burned and the messenger brings the news, Medea enjoys this recounting of her triumph:

But the gold crown held its fastenings firmly, and when she shook her hair, the fire merely blazed up twice as high...Her eyes no longer kept their wonted form nor did her shapely face. From the top of her head blood dripped, mingled with fire, and her flesh dropped from her bones like resin from a pine torch, torn by the unseen jaws of the poison, a dreadful sight to behold. ${ }^{11}$

The classical scholar Michelini argues that in both Neorion's and Euripides' Medea tragedies "paradox is natural to her role as rebel and figure of exception" ${ }^{12}$ She is exceptional in the polis in many ways-Medea is a stranger in a strange land, she is a daughter of a king, she performs daring

\footnotetext{
${ }^{11}$ Medea 1192-94, 1197-1222/ p.405 Kovacs.

${ }^{12}$ Ann N. Michelini, "Neophron and Euripides' Medeia 1056-80" (Transactions of the American Philological Association 119 (1989), p..130.
} 
Journal of Ancient Philosophy Vol. II 2008 Issue 2

deeds with and for Jason. Indeed divinely connected as the granddaughter of Helios the sun. She challenges the submission of women to degradation and betrayal and she pleads their case against the faithlessness of men. At times she speaks justly. But can she speak for any sort of justice if she seems led to a thumoeitic plan of unspeakable cruelty against her rival and even her sons?

I argue that two forms of thumos are in tension here. Medea's pleasure in killing her rival is perhaps the ultimate thumoeitic excess of revenge. But when she is heroically overcoming maternal affection in order to enact the penalty of the gods, something else is present. This is thumos as heroic vigor, the terrible daring that makes heroic acts possible. There is arrogance, and there is arrogation. To call down this duty upon herself is to arrogate power to herself. But once this is done, to fulfill the duty is heroic, since it is one that Necessity imposes upon a mortal. Jason deserves the classic punishment of having his offspring die after breaking his oath to keep Medea as his wife.

Creon's position is also interesting insofar as he represents power and the practical wisdom to protect the city. As he anticipates the danger that Medea poses and banishes her. Medea counters by invoking the privilege of the suppliant.

\section{MEDEA}

Do not, I beg you by your knees and by your newly wedded daughter!

\section{CREON}

Wasted words! You will never persuade me.

\section{MEDEA}

But will you banish me without the regard due a suppliant?

\section{CREON}

Yes, not loving you more than my own house.

$$
\text { M 324-327 }
$$

There is an ordering of duty here: family over strangers, but also protection of the city over mercy for a supplicant. Medea invokes a double grounds for mercy-both with her gesture toward the 
Journal of Ancient Philosophy Vol. II 2008 Issue 2

body of Creon and her attempt to touch his kindness by invoking his newly married daughter. ${ }^{13}$ Yet Creon knows that she has betrayed one city already, perhaps now she arrives to undo another. She appeals to him again as a fellow parent, as one who knows parental love and therefore appreciates the hardship of being forced to leave her sons forever. She asks to remain one day and provide for her children before she leaves for exile. Creon gives in to the reasonableness of this request and makes way for the tragedy to follow.

At other junctures in the play, Euripides' Medea appears in the guise of hero. She is not the same with respect to thumos in its implications for civic life throughout the play. ${ }^{14}$ When she is a mother agonizing over completing a vengeance that is righteous in Zeus's eyes, she deliberates with a spirited soul reminiscent of Homer. Like Odysseus, she encourages herself. Interestingly, being in her right mind is associated with the feeling of spiritedness, and not with complacence.

But what is coming over me? Do I wish to suffer mockery, letting my enemies go unpunished?..I shall not weaken my hand...They must die in any case. And since they must, the one who gave them birth shall kill them. ${ }^{15}$

They must die at all events, and since they must, I who gave them birth shall kill them. Come, put on your armor, my heart! Why do I put off doing the terrible deed that must be done? Come, luckless hand, take the sword, take it and go to your life's miserable goal! Do not weaken... ${ }^{16}$

The boys must die because Zeus decrees that Jason must lose his issue if he betrays his wife.: "This

\footnotetext{
${ }^{13}$ Donald Mastronarde finds a postural excuse for Creon's resisting Medea's supplication at this point: perhaps she only gestures towards Creon's knees and has not yet grasped them tightly. Medea would then be crafty in words but insincere in her gestures. Later she grasps his knees and wins a concession. See Euripides, Medea, edited by Donald Mastronarde (Cambridge University Press, 2003), pp. 225-226.

${ }^{14}$ For more on this interpretation see David Kovacs, "Medea Introduction" and notes passim. Kovacs states that "But while there is no reason to feel pity for Jason, who is portrayed throughout as callous and vain, it is not easy to know what attitude Euripides wants us to take toward Medea." (p.287)

${ }^{15}$ Medea 1049-1050; 1055; 1060-1061/Kovacs p.393.
} 
Journal of Ancient Philosophy Vol. II 2008 Issue 2

man--a god being my helper--will pay the price of his deeds to me. He shall never from this day see his children by me alive, nor will he beget children." ${ }^{, 17}$ Jason must know why his sons are taken from him, and Medea will make that plain. This is in contrast with the vicious attack on her rival which also ends with the death of Creon as he clings to his daughter. As a tragic hero Medea must overcome a temptation to be ordinary rather than exceptional, to be a mere woman rather than a divine granddaughter of Helios, a member of the female sex excused from heroic deeds and the suffering that they entail. Self-justification is the temptation that comes from this weak side, which would give in to maternal love. It is not a fabrication to act according to divine necessity. The text says "And I know well what pain I am about to undergo [tolmeso], but my wrath [thumos] overbears my calculation, wrath that brings mortal men their gravest hurt" 18 She must be willing to submit to this fate and endure it, to stand her ground as much as Odysseus must, having brought it upon herself by invoking the gods' concern with faithful oaths and justice. In translating thumos as 'wrath' and contrasting it with 'calculation', one should consider that such 'wrath' is no longer a private emotion but rather a divine madness that carries forward a penalty that is both divine, and in accord with Medea's desire to cause Jason his gravest hurt.

As with Odysseus and Achilles, Medea's thumos comes to the aid of the agent who must carry out a dreadful plan. Even a woman must rouse up courage and avoid dishonor, since she has no other male relatives that might act for her. Medea is an ambivalent figure for feminist political agents, yet her spirited soul cannot be gainsaid: "What will her proud soul, so hard to check [megalosplagchnos dyskatapautos psyche], do when stung by this injury?" (M 109-110). Sometimes the sanctioned marriage is wrong, the force of state is misapplied, and injustice cannot be tolerated. Achilles is not so completely lost as to rage and kill like Medea, but his situation is different. He battles for the Greeks, she battles for the Gods; still, both justifications provide a cover for selfrighteous excess. Achilles remains intelligible because he has a military duty to kill or be killed.

\footnotetext{
${ }^{16}$ Medea 1240-6 /Kovacs p. 409.

${ }^{17}$ Medea 804-5/ Kovacs p. 369.

${ }^{18}$ Medea 1078-80/ Kovacs p. 394.
} 
Journal of Ancient Philosophy Vol. II 2008 Issue 2

Actuated by friendship and capable of finding a social outlet for his thumoeitic qualities, he returns to battle and does well. Medea has no such social place and for that reason she already the socially explosive and toxic figure. She is dislocated, a stranger, unwanted, and she can play no part in the well-being of civic life.

\section{Thumos disrupts, interrogating authority: the case for disobedience as spirited intellect in action}

Can someone claim to benefit civic life by disrupting it? Can a prompting of the spirited part of the psyche be a registration of political intelligence and civic virtue? Can the heady mix of empathy, vengeful feelings, daring, and plain stubbornness do anything but stumble upon the right action? We have seen that it is the fine line between self-justification and reflectively endorsed actions which separates the self-indulgent spirited wrong-doing from its culturally acceptable and value-specific alternative. This argument does not establish a natural law or other justification for civil disobedience and violence. No universal principle is invoked to ratify the agent's actions. Yet the psychic function of thumos in relation to anger is one of signaling a misalignment of the person in his or her social world with the eternal truths of justice. A distinction should be made between the functioning of thumos in those whose actions are seen as a necessity of social duty, and in those whose actions which principally serve as emotional release. Social duty with respect to obedience to legitimate authority may change, and conflict of roles and allegiances (natural, maternal, divine, human) complicate the picture so that one person's hero/ine is another person's villain.

Yet emotions alone cannot sanction action. For us, thumos cannot function as an independent faculty of truth. There must be a rational element which validates, or consolidates the feeling of injustice with the standard by which one knows what is just or injust. Aristotle's moral philosophy offers one such account. Aristotle concedes that there are various applications and forms of anger that must be judged according to the mean. He marks a right angry response in the absence of which "a man is thought not to feel things nor to be pained by them, and, since he does not get angry, he is 
Journal of Ancient Philosophy Vol. II 2008 Issue 2

thought unlikely to defend himself." (EN 5/1126a ). To endure being insulted and to put up with insult to one's friends is slavish, so anger has a part in courage. This claim that a balance of courage and intellect in citizens is itself a political advantage to the state as a whole seems well founded.

But we observe the same differences [in the proportion of these two qualities] among the Greek nations themselves when we compare one with another: some are by nature one-sided, in others both these natural faculties, of intellect and courage, are well combined. Clearly both are needed... ...fierceness is not a mark of natural greatness of mind except towards wrongdoers. As we have said, it is aroused the more strongly with respect to intimates, when we believe ourselves to be wrongly used by them. ${ }^{19}$

Politics $71327 \mathrm{~b}$ asserts the special merit of being both enthumon and dianoetikon, being both strong of spirit and piercingly intelligent. Here we can find a place for spiritedness and intelligence in a general theory of political and civic action. The spiritedness of thumos is a force in society as well as the individual, in women as well as in men.

A disciplined thumoeitic personality is a possible standpoint for a civic virtue. This would then be a "disciplined irascibility" where thoughtfulness and spiritedness work together to consolidate a social virtue in the individual. This virtue also has a political counterpart: homonoia. Homonoia is the friendship that binds a community together against a common enemy. The desire of a group to be of one mind can also excite resentments among friends. Such ruptures and disruptions are usually bad, but not always, because the one who differs and stands apart can offer a corrective standpoint that is to the benefit of the community. To act out the rupture through a disruption of supposed unanimity can be beneficial, like draining a festering wound. Indeed, to fail to take the side of justice is to court stasis, the Greek term for political terminal illness. When the civic order is out of order, there is virtue in refusing to be orderly. This is where there is a unique benefit to the examination of what might be thought to be archaic, and therefore, outdated, concepts in Greek philosophy. The discussion of thumos and the value of the daring personality in political

${ }_{19}$ Politics 7: 1327b, translated by T. A. Sinclair and revised by Trevor J. Saunders (Penguin, 1981). 
Journal of Ancient Philosophy Vol. II 2008 Issue 2

discourse should continue. I hope that further research will make plain the complexity of motivations that actuate political participation as well as violence. My hope is that that this study has furthered that understanding.

\section{Bibliography}

Aristotle. Ethica nicomachea. The Nicomachean Ethics, Translated by Sir David Ross. Oxford World's Classics. London and Oxford, 1961.

Aristotle. Politica. The Politics. Translated by T.A. Sinclair and revised by Trevor J. Saunders. Penguin Books, 1981.

Caswell, Caroline P. A Study of Thumos in Early Greek Epic. E.J. Brill, 1990.

Euripides. Medea. Euripides: Cyclops/Alcestis/Medea. Translated by David Kovacs. Loeb Classical Library v.12. Harvard, 1994.

Euripides. Medea. Edited and Commentary by Donald Mastronarde. Cambridge University Press, 2003.

Frère, Jean. les Grecs et le désir de l'etre : des préplatoniciens à Aristotle, Société d'Edition «Les Belles Lettres ». Paris, 1981.

Kalimtzis, Kostas. Aristotle on Political Emnity and Disease. State University of New York Press, 2000.

Katz, Joshua T. "Homeric Hymn to Hermes 296", Classical Quarterly New Series Volume 49 number 1 (1999).

Michelini, Ann N. "Neophron and Euripides' Medeia 1056-80" . Transactions of the American Philological Association 119 (1989).

Plato. Republic. Translated by Robin Waterfield. Oxford World's Classics, 1998. 